\title{
Formation of personal qualities by means of acmeological approach in the context of professional becoming
}

\author{
A.G. Mikhaylova ${ }^{1 *}, M . V$. Nikitaeva $^{2}$, and T.A. Kokodey ${ }^{3}$ \\ ${ }^{1}$ Sevastopol State University, Sevastopol, Russia; Nakhimov Black Sea Higher Naval School, \\ Sevastopol, Russia \\ ${ }^{2}$ Moscow City University, Moscow, Russia \\ ${ }^{3}$ Sevastopol State University, Sevastopol, Russia
}

\begin{abstract}
The article deals with the problem of personal skills formation in the context of modern system of higher education. It is proved that acmeological approach provides the graduate's ability to adapt to practical activity successfully in contradictory and constantly changing conditions. The growing interest in this scientific problem is due to the fact that professional training at the university today is actively involved in the global processes of education modernization for the purposes of sustainable development.
\end{abstract}

\section{A problem statement}

Socio-economic progress has an impact on the material and spiritual aspects of the state life in general and each individual, that requires the innovative approaches development to the educational process at the university [1].

The educational process is learning, communication, where there is controlled cognition, assimilation of social and historical experience, reproduction, mastery of one or another specific activity that underlies the formation of personality. In general, we consider the university educational process as one, which is aimed at solving the problems of education, upbringing and personal development. In nowadays, the welfare of the society is considered to be the most important aspect in the formation of personality character traits [2].

The formation of a new personality-developing education means the personality and its individual abilities development (A.G. Asmolov, V.V. Davidov, A.A. Derkach, E.V. Selezneva, I.S. Yakimanskaya). "The individualization of education necessitates of new models of teaching and upbringing creation that ensure the problems solution of personal and professional development for different groups of students" [3].

The methodological basis for the study is a theory of readiness for various types of activities by P.A. Rudik, E.P. Ilyin, M.D. Levitov, the theory of communication by B.G. Anan'ev, A.A. Bodalev, M.S. Kagan, A.A. Leontiev, A.N. Leontiev, B.G. Lomov. When

*Corresponding author: steba1971@mail.ru 
studying the psychological aspects of higher professional education, including the problems of personality development, we referred to the works of K.A. Abulkhanova-Slavskaya, A.A. Derkach, L.S. Vygotsky, V.G. Zazykin, S.L. Rubinstein, V.I. Slobodchikov and others. So, M.S. Kagan defines communication as intersubjective interaction in the process of which the development of personal qualities occurs [4]. N. Stafeeva, I. Medvedeva, A. Bulashova and M. Zaichkosaid that consecutive and purposeful realization in university educational process provides effective formation of an acmeological orientation of students' identity that is the most important result of realization of acmeological approach in a system of professional becoming [5].

Focusing on the subjectivity of the communication process, B.F. Lomov and M.S. Kagan emphasize the importance of the interactive structural component in the process of interpersonal interaction [4]. So, Y.G. Zinatdinova states that relations as a kind of integral system are reflected in ones based on conscious choice or with the material world relationship, their integration with other members of society in the ability to build relationships and communication [6].

The purpose of this study is to systematize modern approaches to solving the problem of personal qualities formation on the basis of an analysis of foreign and domestic experience that provide the ability of a graduate to adapt to practical activities successfully.

To achieve the goal, the following tasks have been set:

1. To determine the potential of the educational process of the university in personal qualities formation.

2. To substantiate and realize the conditions for the effective personal qualities formation, taking into account the systematization of modern approaches to solving this problem.

The object of the research is personal qualities. The subject of one is the process of forming personal qualities within the framework of professional development.

\subsection{The objective of the work}

The methodological basis of the research was formed by the ideas of domestic psychologists and teachers about the relationship between learning and communication, understanding the didactic process as communicative, the theory of readiness for various types of activities by E.P. Ilyin, P.A. Rudik, M.D. Levitov A.N. Leontyev and etc.

To achieve the purpose of our study, a set of complementary theoretical research methods was used: a literature review on the issue under consideration; analysis, synthesis and systematization of the main approaches to solving the research problem. Diagnostic techniques in order to determine the levels of personal qualities formation are the following:

- Locus of control;

- Diagnostics "Determination of the need to achieve a goal, self-regulation";

- Diagnostic technique of success motivation by T. Ehler;

- Diagnostics of empathic tendencies by I.M. Yusupov;

- "Relationship with the interlocutor" testby S.A. Budassi;

- Study of value orientations by M. Rokich;

- SWOT analysis of personality characteristics.

\section{Materials and the results of the research}

Many researchers have studied theoretical acmeological fundamentals for the person's development meeting the needs for society reformation [3, 5, 7, 8-10]. In modern 
conditions the society requires scientifically justified means of personality development [11].

Having considered theoretical aspects of approaches to defining the essence of the concept of "interaction" we determined several positions: a specific type of communication associated with mental contact between real subjects and leading to their mutual influence, mutual understanding and mutual experience; a term is similar to one of communication, but more extended.

Interaction id determined by its main social functions: regulating, organizing (managing), evaluating, stabilizing and educating. In general, it can be stated that in the process of communication there is a mutual exchange of actions, attitudes, perceptions, interests, ideas, ideas, etc., the system of relations "subject-subject (s)" develops and manifests itself. Communication is intersubjective interaction, which should promote mutual understanding.

As A.A. Derkach stated, a profession as a system of tasks, forms and types of activity requires specialists who have relevant professionally important qualities and are able to effectively solve professional tasks. At the same time, a person as a subject of activity requires from the profession the ability not only to receive necessary means of his/her existence and development in return for the labor expended, but to reveal his/her creative potential and self-realization [3].

The integral pedagogical process which provides the self-realization of the individual is characterized by the internal unity of its constituent components and their harmonious interaction [12]. The integrity of the process in terms of content is ensured by the reflection of experience in the goal and content of education. Organizationally, the property of integrity is acquired by the educational process if the interaction between teachers and students and the development of the content of education by students without the direct participation of the teacher is ensured. The technological aspect of the integrity of the pedagogical process involves an appeal to the educational process from the standpoint of subject relations.

The problem of personal understanding is associated with the content of research on interpersonal relationships, which are a specific type of subject relationship, on the basis of which interaction, mutual influence, empathy and productive results of professional activity take place [1].

Since the methodological approach sets a model for seeing, understanding and interpreting pedagogical phenomena, the acmeological approach is taken as a basis. Studies of personal and professional development in acmeology have shown that there is a development of personal qualities in the structure of the personality in the course of this process. From an acmeological point of view, a professional is a subject of activity who possesses such mental properties which provides professional activity performance at a high level of productivity [13].

Despite a significant number of studies carried out by various authors, today there is no single generally accepted model for classifying personal and business qualities as the main characteristics of a professional.

In the opinion of many scientists, professional standards should provide solving professional and psychological problems of improving the professional activity of specialists in accordance with innovative requirements. In this case, the role of practical psychologists in the psychological support of the professional activities of various specialists is important. The main tasks of psychologists are as follows: research on improving the quality of professional activity of specialists in accordance with their psycho physiological capabilities and taking into account situations in accepted practice; psychological theory and practice of one will be specifically aimed at becoming a professional. 
The basic principles of teaching as requirements for the organization of the educational process, arising from historical experience, are the activity of the students; the strength of the assimilation of knowledge, skills and abilities in combination with the experience of creative activity, the connection between theory and practice.

The implementation of complex of pedagogical conditions for professionally significant personal qualities formation of future specialists was executed by means of pedagogical work organization of different forms in the context of university studying: extracurricular activity, specially organized for development of projects, the educational process itself and so on.

Based on the analysis of philosophical, psychological, sociological, pedagogical, engineering literature on the problem under consideration, we have clarified and supplemented the concept of "personal qualities", which we understand as possession of the ability to manage current events, form positive and constructive interpersonal relationships, organizational, intellectual abilities and the ability to be open to life and social experience.

The subjects of interpersonal relationships are certain personalities who have unique individual qualities that are revealed in the course of communication and the organization of joint actions, and also possess communication strategies, including: the ability to create partnerships based on mutual respect, mutual understanding, trust and providing a solution to conflict situations during which the joint acceptance of the goals of the activity is realized. The exchange of creative ideas, values, and feedbacks occur in the main form of reflexive processes.

We consider the development of personal qualities as a personality formation focused on high professional achievements and his/her professionalism in the course of selfdevelopment, professional activity.

According to A.A. Derkach opinion [3], socialization and individualization are interrelated aspects of a single process of personal and professional development from the point of acmeology: a person masters a social experience, but at the same time acquires an independence and autonomy.

The impetus of a personal qualities formation is a contradiction, namely: one between individual's abilities, giftedness, motivation for achievements and the requirements of specific professional activities.

We understand personal qualities formation as mastering new technologies and algorithms for solving professional problems, improving the style of activity, changing the system of motives and values. They are components of a person's professionalism. Comparing the elements of various technologies, such as "learning in cooperation" (problem-based, project-based learning), search and research technology, game learning, we came to the conclusion that modern technologies are based on well-known techniques: TRIZ, ARIZ, Brainstorming, etc.

As a result of personal development: there is an expansion of the subject environment of the individual, professional and moral enrichment of the individual, including an increase in responsibility, sense of duty, conscience and honor; the orientation of the personality changes (the range of interests expands, the system of needs changes, the motives of achievement are actualized, the need for self-development increases, the creativity of the individual increases). Complex person's abilities, professionally important and personal qualities are developed (organization, diligence, initiative, discipline, normative behavior); acmeological invariants of professionalism are formed (anticipation, self-regulation, figurative sphere, the ability to make decisions, etc.); personal potential is revealed, the system of motives and values changes, and motivation for self-development and professional achievements take the dominant places in its hierarchy; a productive professional self-concept is formed. And, at last, a system of professional standards of activity and behavior is developed; the psychological readiness for activity in various, 
including complicated, situations increases; experience is gained and qualifications are raised, professional competence is formed, creativity is increased, the individual style of activity is improved. Psychological factors that impede personal and professional development are: nature-conditioned limitations, "blurring", and ambiguity of goals and motives of achievement, negative moral and psychological climate in team.

We believe that four dynamic components provide the results achievement in the development of person's professionalism:

- cognitive (formation of knowledge underlying professional activity);

- value (of values and motives formation);

- activity (organizational and communication skills formation which provide person's selfdevelopment);

- reflexive (the formation of semantic determinants of self-perception, self-realization and self-efficacy).

The cognitive component provides knowledge mastering in the professional field, the moral regulation of professional activity, and self-knowledge skills formation.

As cognitive component involves a person's belief / knowledge about an attitude object, we agree that one of the underlying assumptions about the link between attitudes and behavior is that of consistency we usually expect person's behavior to be consistent with the attitudes. The main principle there is one of consistency.

The value component provides a set of motives and internal conditions formation which direct and regulate the process of becoming professionalism, goal-setting, motivation for success and avoidance of failures in the process; the need for positive self-perception.

The activity component involves formation of technologies system in the field of selfdevelopment.

The reflexive component is aimed at understanding one's individual psychological characteristics, the level of professionalism, the presence of self-assessment of the results of activity and awareness (the need to accept the norms of society, the choice of productive methods of activity).

Diagnostic techniques that involve determining the levels of personal qualities formation are the following: Locus of control [14], a diagnostic technique for motivation for success by T. Ehlers, Diagnostics "Determination of wishes to achieve a goal, selfregulation", diagnostics of the level of empathic tendencies by I.M. Yusupov, test "Relationship with the interlocutor" and S.A. Budassi, a study of value orientations according to M. Rokich, SWOT analysis of personality characteristics [15].

SWOT Analysis is a useful technique that helps you to identify strengths and weaknesses, and analyze the opportunities and threats that flow from them. To perform a personal SWOT analysis, first answers to the following questions.

\section{Strengths}

What personal skills do you have that others don't have?

What personal resources can you access?

Which of obtained achievements are you proud of?

\section{Weaknesses}

What tasks do you usually avoid for you don't feel confident doing them?

What will the people around you consider as your weaknesses?

Are you confident in your education and skills training?

Opportunities

What innovative technology can help you?

Are your personal skills growing? If so, how can you take advantage from them?

Threats

What obstacles do you currently face in the university?

Are any of your friends competing with you for projects? 
This method provides the ability to think through the things which are important to any person, and set the compelling personal goals that motivate you towards success. Personal SWOT analysis can be an excellent exercise to brainstorm a particular moment in one's life and improve oneself $[15,16]$. Locus of control is a psychological concept that refers to how a person believes she/she has control over the situations and experiences that affect his/her life. In education, locus of control typically means students' ability of perceiving the causes of their academic success or failure in the course of professional becoming. Whether a student has an internal or external locus of control is considered to have a powerful effect on persistence, academic motivation, and achievement in the university. So, students with learning disabilities can develop an external locus of control due to negative experiences and external factors are likely to develop into a psychological coping mechanism (i.e., when someone is always the cause, the student doesn't need to take more responsibility over his/her success) [17].

Several questionnaires have been developed to help identify whether persons tend toward an internal or external locus of control. Julian B. Rotter, the psychologist who was the first to develop the locus-of-control concept, created question-based assessment and a scale designed to determine where he/she is on the internal-external spectrum. The test offers choices between two ones: the respondent would choose between "I have often found that what is going to happen will happen" or "Trusting to fate has never turned out as well for us as making a decision to take a definite course of action." Rotter's evaluation is one of a number of diagnostic instruments and scales that should be used by psychologists and educators.

Experimental work to test the effectiveness of support methods includes the diagnosis of personal qualities at the initial stage of professional training, as well as a control of the formed personal characteristics after the formative stage of the research. The substantiated experimental methodology and pedagogical conditions were implemented in the natural conditions of the pedagogical experiment during 2018-2020 on the basis of the Sevastopol State University. The sample range, ensuring the representativeness of the data, was determined at 100 people (55 students of the "bachelor" level in the control group and 45 ones of the "bachelor" level in the experimental group) training in the direction 27.03.04 Management in technical systems (profile - Intelligent control systems and data processing (Smart systems)). On the basis of various empirical data obtained using the methods, the average value of each level of personal qualities formation (X) was determined by the formula, namely high, middle, low (1):

$$
x=\frac{\sum}{n}
$$

where $\Sigma$ - sum of indicators; $\mathrm{n}$ - number of indicators. The results of the ascertaining experiment are presented in table 1 and Figure 1, which illustrate the average value of each level of personal qualities formation.

Table 1. Results of the ascertaining and control stages (\%).

\begin{tabular}{|c|c|c|}
\hline Levels & Experimental group & Control group \\
\hline \multicolumn{3}{|c|}{ Ascertaining stage } \\
\hline high & 22 & 24 \\
\hline middle & 31 & 29 \\
\hline low & 47 & 47 \\
\hline \multicolumn{3}{|c|}{ Control stage } \\
\hline high & 57 & 29 \\
\hline middle & 34 & 41 \\
\hline low & 9 & 30 \\
\hline
\end{tabular}

Source: compiled by the authors. 


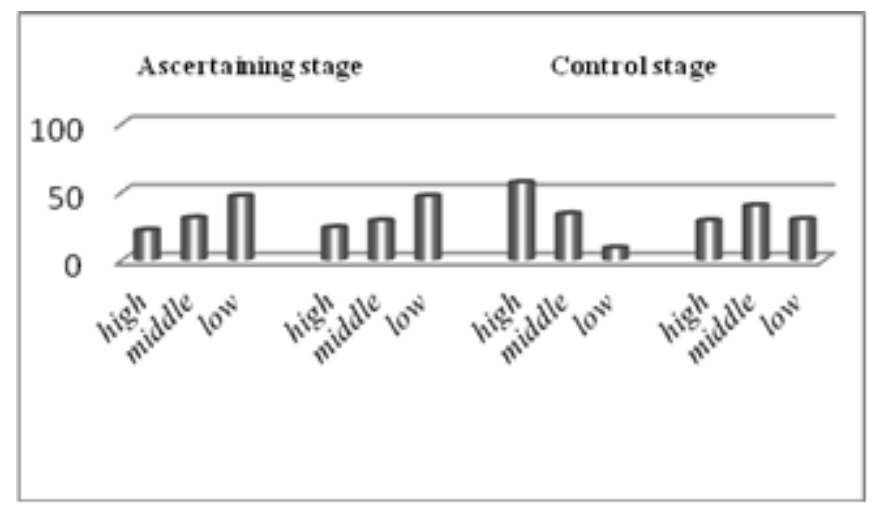

Fig. 1. Average value of levels of personal qualities formation.

To compare the empirical distributions of the levels of personal qualities formation, Student's coefficient was used. By the end of the study, the students of the experimental group significantly differed from the representatives of the control group in terms of the level of the studied qualities formation: there were more students than in the control group who reached a high level, and significantly less - those having a low level.

To achieve this result, we used project activities based on the methods of Theory of Inventive Problem Solving (TRIZ) and Brainstorming [18]. Project activity is the basic pedagogical technology, which provides personal qualities forming; the implementation took place through communication, obtaining one's own product of activity and awareness of its significance. A factor favorable for organizing the project activities of students at this stage was the participation in the presentation of works at the scientific and practical conference of scientists "Recent Achievements and Prospects of Innovations and Technologies" [19].

TRIZ is a systematic approach for understanding and solving any problem and a catalyst for innovation and invention. By means of clear thinking and innovative ideas generation, TRIZ helps to obtain an ideal solution without the need for compromise. We have used TRIZ matrix gathering 40 Principles (known solutions) which are able to overcome the contradictions.

Brainstorming is based on a relaxed, informal approach to problem solving with lateral thinking. It encourages people to come up with thoughts and different ideas. Some of ideas can be crafted into original, creative solutions to a problem, while others can spark even more ideas. This method provides a generation of radical solutions to problems.

\section{Conclusions}

As the results of numerous studies show, professionalism formation is closely interconnected with personal development. Achieving professionalism implies mastering the most important personal and professional qualities, character traits, intellectual qualities, disclosing the creative potential of a person and his/her moral improvement.

This research suggests ways to improve the professionalism of a future specialist. The article presents the results of an experimental study to test the levels of future professional's personal qualities formation. Diagnostic techniques that involve determining the levels of personal qualities formation are presented. The substantiated experimental methodology and pedagogical conditions were described. Four dynamic components provide the results achievement in the development of person's professionalism: cognitive (formation of knowledge underlying professional activity); value (motives formation); activity 
(organizational and communication skills formation which provide person's selfdevelopment); reflexive (the formation of semantic determinants of self-perception, selfrealization and self-efficacy).

The implementation of complex of pedagogical conditions for professionally significant personal qualities formation of future specialists was executed by means of acmeological approach which provides integrating the potential of professional becoming in the system of higher education and assist in students' professional and personal development.

\section{References}

1. T.A. Kokodey, A.G. Mikhaylova, T.V. Smirnova, International Comparison of Consumer Behaviour between the Young Generation in Taiwan and Japan within the Framework of Pedagogical Management, Social and Cultural Transformations in the Context of Modern Globalism, LXXVI, 1695-1704 (2019)

2. O. Fadeeva, The significance of personal qualities of student's formation within the physical education, Procedia. Social and Behavioral Sciences, 136, 416-420 (2014)

3. A.A. Derkach, Psychological and acmeological foundations and means of optimizing the personal and professional development of a competitive specialist, Acmeology, 11, 10-12 (2012)

4. M.S. Kagan. The world of communication, The problem of inter subjective relationships, p. 319 (Moscow, 1988)

5. N. Stafeeva, I. Medvedeva, A. Bulashova, M. Zaichko, Acmeological Approach as a Factor of Professional and Pedagogical Selfrealization of Students of a High Educational Institution at Studying of Foreign Languages, IOP Conference Series: Earth and Environmental Science, 272, 3 (2019)

6. Y.G. Zinatdinova, The formation of personal qualities of primary school students based on the provision of creative activity, European Journal of Research and Reflection in Educational Sciences, 10, 62-64 (2019)

7. I.A. Zimnyaya M.D. Lapteva, On innovation in educational process (Focus on competence oriented curriculum), Akmeology, 1, 32-36 (2009)

8. V.S. Efimov, A.V. Lapteva, Higher Education in Russia: Challenges of the XXI Century, Journal of Siberian Federal University, 1, 143-154 (2011)

9. E.A. Shmeleva, Innovation Potential of Acmeological Approach to Teaching Staff Training Journal of Siberian Federal University, 9, 1235-1245 (2012)

10. I.V. Abakumova, P.N. Ermakov, M.V. Godunov, Polar Meaning-Building Strategies: Acmeological Characteristics, Personality psychology, 11, 200-210 (2018)

11. B. Turgunbayeva, B. Bekzhanovab, E. Uaidullakyzyc, D.A. Arkhabayeva, Procedia. Social and Behavioral Sciences, 89, 544-548 (2013)

12. Zh.B. Shaimakova, Role of innovative competence of development of competitiveness of the teacher of the higher school, Akmeology, 2, 38-45 (2009)

13. I.V. Balynin, N.N. Nizhneva, A.G. Mikhaylova, Design activity skills formation in future economists, 1st International Scientific Conference. Modern Management Trends and the Digital Economy: from Regional Development to Global Economic Growth. Atlantis Press, (MTDE, 2019)

14. A.G. Mikhaylova, T.A. Kokodey, Development of universal competencies of the individual in the context of noogenesis, Actual issues of economics and pedagogy in modern conditions of digital transformation: materials of the I All-Russian 
interdisciplinary scientific-practical conference of students, graduate students and young scientists. REU G.V. Plekhanov, Sevastopol: Publishing house of the Sevastopol branch of the FSBEI "Russian University of Economics. G.V. Plekhanov", 109-114 (2019)

15. A.G. Mikhaylova, I.V. Balynin, N.N. Nizhneva, SWOT-Analysis of Information Technologies Application to Form Future Managers' Communicative Competence, Proceedings of the International Scientific and Practical Conference on Digital Economy (ISCDE, 2019)

16. G.A. Guthrie. Comprehensive guide to creating your personal SWOT Analysis. Strategy \& Planning, Nov 13, access mode: https://cacoo.com/blog/a-comprehensiveguide-to-creating-your-personal-swot-analysis/ (2018)

17. E.P. Ilyn, Psychology of communication and interpersonal relations, p. 576 (Piter, 2009)

18. Locus of control. Access mode: https://www.edglossary.org/locus-ofcontrol/\#: : text=Locus $\% 20$ of $\% 20$ control $\%$

20is\%20a,success\%20or\%20failure\%20in\%20school (2020)

19. TRIZ 40. Access mode: http://www.triz40.com/TRIZ_GB.php (2020)

20. Recent Achievements and Prospects of Innovations and Technologies, Materials of IX All-Russian Scientific and Practical Conference of Students, Postgraduates and Young Scientists, 267 (Kerch, 2020) 